\title{
Research Design Proposal for Investigation of Site 41BU16 Burleson County, Texas
}

Follow this and additional works at: https://scholarworks.sfasu.edu/ita

Part of the American Material Culture Commons, Archaeological Anthropology Commons, Environmental Studies Commons, Other American Studies Commons, Other Arts and Humanities Commons, Other History of Art, Architecture, and Archaeology Commons, and the United States History Commons

Tell us how this article helped you.

This Article is brought to you for free and open access by the Center for Regional Heritage Research at SFA ScholarWorks. It has been accepted for inclusion in Index of Texas Archaeology: Open Access Gray Literature from the Lone Star State by an authorized editor of SFA ScholarWorks. For more information, please contact cdsscholarworks@sfasu.edu. 


\section{Research Design Proposal for Investigation of Site 41BU16 Burleson County, Texas}

\section{Licensing Statement}

This is a work produced for the Texas Department of Transportation (TxDOT) by the report producer. TxDOT and the report producer jointly own all rights, title, and interest in and to all intellectual property developed under TXDOT's contract with the report producer. The report may be cited and brief passages from this publication may be reproduced without permission provided that credit is given to both TXDOT and the report producer. Permission to reprint an entire chapter, section, figures or tables must be obtained in advance from either the Supervisor of the Archeological Studies Branch, Environmental Affairs Division, Texas Department of Transportation, 125 East 11th Street, Austin, Texas, 78701 or from the report producer. 
Research Design Proposal for Investigation of Site $41 \mathrm{BU} 16$ Burleson County, Texas

Texas

State Department of Highways and Public Transportation

Highway Design Division

December 1983 
Reading Site

Kesearch Design

The Reading Site, 41BU16, is a prehistoric and historic site located in Burleson County, Texas, on the south terrace of the Brazos River at the crossing of State Highway 21. The site was first reported in 1972 but was not known to extend into the right-of-way of SH 21 until the clearing of heavy brush in the right-of-way in 1979 revealed its presence. Since that time the site has been known by local collectors, but the archaeology section of the State Department of Highways and Public Transportation (SDHPT) was not notified until August 25, 1983.

Since the bridge construction project was begun in May, 1983, the site has already been dramatically impacted by construction activities. A portion of the site remains intact within the right-of-way. This area is approximately 10 by 45 meters in extent and was the subject of the testing report.

The site is also the location of significant historic activities. Moseley's Ferry operated continuously at the site from 1846 to 1912 . It was located along both a major navigable river and what was at that time the only surveyed road through Texas, the Camino Real or King's Highway. This road was laid out in 1691. Adding to the historic significance of the ferry's locale was its proximity to Stone City, a station on the Hearne and Brazos Valley Railroad established in 1891; Stone City continued to be a viable community through 1940. There are no buildings extant on the site today. Documentary research into the background of the site and ferry operation has already begun and is to be completed prior to excavation of the site. 
All archaeological activities will be performed in accordance with 36 CFR 66 , Recovery of Scientific, Prehistoric, Historic, and Archaeological Data: Methods, Standards, and Reporting Requirements and be consistant with the Council of Texas Archeologist Guidelines for archaeological recovery. Excavation will be performed in accordance to a meter grid pattern. Units will be dug to sterile in arbitrary ten centimeter levels. All excavated material will be passed through 0.25 inch hardware cloth screen with artifacts catalogued by unit and level. Specifically, the mitigation of the adverse effects caused by this project and to comply with the provisions under $36 \mathrm{CFR} 800.7$ (a) and to be consistant with the Memorandum of Understanding is as follows:

1. The west profile, as exposed in a construction cut bank, will be cleared and recorded.

2. Four 1 meter square units along the eastern margin of the right-of-way will be excavated by hand and will be in line with those test units previously excavated, (TU 1-4) .

3. A trench one meter wide and at least five meters long will be excavated by hand across the cut and fill (gully/ditch) observed in the western profile of the cut bank.

4. A five meter square block (25 square meters) will be excavated in the area of greatest productivity. The placement of this block will be determined from the results of the tests conducted in September, 1983, and those excavations conducted under items 2 and 3 above.

5. A standard size sample of the deposits beginning $30 \mathrm{~cm}$ below the surface will be recovered from each of the excavation units along the right-of-way, the trench, and opposing corners of the block unit for water screening, flotation 
recovery and analysis. A 10 by $10 \mathrm{~cm}$ section the thickness of the excavation unit is suggested. Similar samples should be taken from all features and burials encountered. No samples will be taken in the upper 30 an since these deposits were dramatically disturbed in clearing operations.

6. All the analysis identified in the scope of work and research design will be accomplished and reported as appropriate to the data and materials recovered.

7. The following reports will be prepared: a) an interim project letter report submitted to the SDHPT outlining the results of the field investigation will be provided to the SHPO, Corps of Engineers, and Department of the Interior's Consulting Archeologist within 60 days of completion of the field work; b) a final technical report conforming to the guidelines presented in draft 36 CFR 66, Appendix A and consistent with the Report Standards guidelines of the Council of Texas Archeologists, within 12 months of contract award; and c) a popular report of the investigations such as press releases, media presentations, or an economically produced pamphlet or brochure, disseminated to the public.

8. As the archaeological materials and data form a portion of the cultural heritage of the State of Texas and are state property, they will be curated in accordance with the Curation Standards of the Council of Texas Archeologists. Final disposition and curation of a 11 data will be determined at the end of the analysis period.

It is anticipated that the excavation, laboratory analysis, and writing of the report will be performed through the Archeological Research Laboratory, Texas A\&M University, College Station, Texas. The research laboratory is under the general supervision of Dr. David L. Carlson. It is estimated that 
excavation will require four to six individuals and should be completed within two months.

Preliminary testing of archaeological site 41 BU16 revealed at least three components of cultural occupation at the site. The earliest, as identified by stone tools and dart points, is Archaic. Above the Archaic is a zone containing mixed Late Prehistoric and Historic artifacts. It is anticipated that only those zones below the top $30 \mathrm{~cm}$ will contain intact features and are expected to be Archaic in age. It is also anticipated that information will be uncovered early in the proposed excavation which will lead to declaration of affiliation hypothesis. The real value of 41BU16 lies in the potential for recovery of data in an area from where there has been little published.

Analysis of recoverable microfauna, microflora, and pollen are planned. Soil samples will be taken for fine screening and flotation. If recovered radiocarbon samples will be submitted for dating. Environmental results will be of value when combined with artifactual data.

Relationship of the historic record to the artifactual evidence at the site will be important to historic interpretations. Seasonality of the prehistoric occupation, past environmental conditions, and subsistence strategies at this juncture of the Brazos River are topics which can also be addressed during excavation. As with any dynamic approach to research, dating the occupations, along with the other topics mentioned, will be refined as the data are collected. Some specific research directions regarding 41BU16 are as follows: 
1. A major concern at the site was the establishment of Moseley's Ferry which operated between 1846 and 1912. There were also habitations and businesses in the area up to and after 1950. None of these exist today. As regards to the Texas State Historic Preservation Plan, 41BU16 is included within the Upper and Lower South (Period Two) Study Units; thus the historic materials present at the site may have the potential to reveal particulars concerning westward expansion and the steady migration of United States' citizens into Texas through the end of the nineteenth century. A segment of the same study will be the sites role in development of transportation systems in the State of Texas.

2. A feature found prior to testing was that of a prehistoric burial. Although this may have been an isolated interment, there remains the possibility of others being found. Should more burials be found they will be subject to osteological analysis and determination of cultural relationships. This data will be important in studies of prehistoric burial practices in the region.

3. Through excavation of the cultural deposits, a chronology for the site can be formulated. This, in turn, can be compared to the chronological constructs which exist for surrounding regions. The recovery of diagnostic lithic tools from Site 41 BU16 is expected to be very good and will be important in establishing the sites relationship to the immediate area as well as to the overall cultural framework in the State of Texas.

4. Examination of the chipped stone material recovered in testing and a review of the literature would indicate relationships of the prehistoric components to the Central Texas Archaic (Weir 1976), the Lake Limestone area (Mallouf 1979) and Robertson County (Prewitt 1975) north of the site, and the Lake Somerville area, Burleson County (Peterson 1965) south of the 
site. The pottery from the site appears related to ceramics from the Lake Conroe area (Shafer 1968) in Montgomery County east of the site.

Data correlation with these areas, as well as with other sites, will serve to bring into focus aspects of chronology, subsistance strategies, and function, and will also serve to manifest a security in our knowledge gained from the Reading Site, 41BU16. 


\section{References Cited}

Mallouf, Michael G.

1979 Archaeological Investigations at Lake Limestone. Texas Archeological Survey Research Report No. 71, The University of Texas, Austin.

Peterson, Frederick A.

1965 The Erwins Bridge Site at Somerville Reservoir, Burleson County, Texas. Texas Archeological Salvage Project, University of Texas, Austin.

Prewitt, Elton R.

1975 Upper Navasota Reservoir: Archeological Test Excavations at the Barkley and Louis Sadler Sites. Texas Archeological Survey Research Report No. 33, University of Texas, Austin.

Shafer, Barry $\mathbf{J}$.

1968 Archeological Investigations in the San Jacinto River Basin, Montgomery County, Texas. Archeological Salvage Project

Paper 13. University of Texas, Austin.

Weir, Frank A.

1976 The Central Texas Archaic. Unpublished Ph.D. dissertation, Washington State University, Pullman. 